\title{
Regulation of feeding behavior and psychomotor activity by corticotropin-releasing hormone $(\mathrm{CRH})$ in fish
}

\author{
Kouhei Matsuda* \\ Laboratory of Regulatory Biology, Graduate School of Science and Engineering, Graduate School of Innovative Life Science, University of Toyama, Toyama, Japan
}

\section{Edited by:}

James A. Carr, Texas Tech

University, USA

Reviewed by:

James A. Carr, Texas Tech

University, USA

Larry Riley, California State

University at Fresno, USA

*Correspondence:

Kouhei Matsuda, Laboratory of

Regulatory Biology, Graduate School

of Science and Engineering,

Graduate School of Innovative Life

Science, University of Toyama,

3190-Gofuku, Toyama 930-8555,

Japan

e-mail:kmatsuda@sci.

u-toyama.ac.jp
Corticotropin-releasing hormone $(\mathrm{CRH})$ is a hypothalamic neuropeptide belonging to a family of neuropeptides that includes urocortins, urotensin I, and sauvagine in vertebrates. $\mathrm{CRH}$ and urocortin act as anorexigenic factors for satiety regulation in fish. In a goldfish model, intracerebroventricular (ICV) administration of $\mathrm{CRH}$ has been shown to affect not only food intake, but also locomotor and psychomotor activities. In particular, $\mathrm{CRH}$ elicits anxiety-like behavior as an anxiogenic neuropeptide in goldfish, as is the case in rodents. This paper reviews current knowledge of $\mathrm{CRH}$ and its related peptides derived from studies of teleost fish, as representative non-mammals, focusing particularly on the role of the $\mathrm{CRH}$ system, and examines its significance from a comparative viewpoint.

Keywords: goldfish, CRH, ICV injection, food intake, anorexigenic action, psychomotor activity, anxiogenic-like action

\section{INTRODUCTION}

Corticotropin-releasing hormone (CRH), a 41-amino-acid neuropeptide present in the brains of vertebrates, was first isolated and characterized from the ovine hypothalamus (Vale et al., 1981), and then subsequently identified in non-mammalian brains (Lovejoy and Balment, 1999). CRH is a member of a family of related peptides that includes urotensin-I (UI), sauvagine, and urocortin/stresscopin in vertebrates (Lovejoy and Balment, 1999; Boorse and Denver, 2006). In mammals, CRH is known to induce the release of adenohypophyseal hormones such as adrenocorticotropic hormone (ACTH), $\beta$-endorphin, and $\alpha$-melanocyte-stimulating hormone $(\alpha-\mathrm{MSH})$ from the pituitary, and there is ample evidence that $\mathrm{CRH}$ and its related peptides play multiple roles in animal development and also in physiological and behavioral adaptation to environmental changes and energy balance (Tonon et al., 1986; Hauger et al., 1988, 2006; Lowry and Moore, 2006; Cooper and Huhman, 2007; Denver, 2009; Papadimitriou and Priftis, 2009; Chen et al., 2012; Kubota et al., 2012).

In non-mammalian vertebrates such as amphibians and teleosts, CRH acts as a potent stimulator of corticotropin, thyrotropin, and $\alpha-\mathrm{MSH}$ release (Boorse and Denver, 2004, 2006; Calle et al., 2005; Ito et al., 2006; Okada et al., 2007). CRH and its related peptides also act as regulators of feeding behavior and stress responses in vertebrates including mammals, birds, amphibians, and fish (Kalra et al., 1999; Bernier and Peter, 2001; Ohgushi et al., 2001; Hillebrand et al., 2002; Tachibana et al., 2004; Saito et al., 2005; Lowry and Moore, 2006; Carr et al., 2010; Matsuda et al., 2010b; Morimoto et al., 2011; Khan et al., 2013). It has been reported that, in the goldfish, intracerebroventricular (ICV) administration of CRH or UI exerts an anorexigenic action (de Pedro et al., 1997; Bernier and Peter, 2001; Volkoff et al., 2005; Matsuda, 2009), which is blocked by treatment with a CRH
1/CRH 2 receptor antagonist, $\alpha$-helical $\mathrm{CRH}_{(9-41)}$ (de Pedro et al., 1997; Bernier and Peter, 2001; Bernier, 2006; Maruyama et al., 2006). In fish, ICV administration of CRH also affects locomotor activity (Clements and Schreck, 2004; Maruyama et al., 2006; Carpenter et al., 2007; Backström et al., 2011a; Ghisleni et al., 2012; Matsuda et al., 2013b), suggesting that CRH exerts psychophysiological effects in fish. Recent reports indicate that a fish's swimming pattern can be used to evaluate psychomotor activities, notably anxiety-like behavior (Faganello and Mattioli, 2007; Grossman et al., 2010; Maximino et al., 2010a,b; Matsuda et al., 2011a,b, 2013b; Blaser and Rosemberg, 2012; Maaswinkel et al., 2012). Therefore, the present mini-review summarizes recent advances in knowledge about the regulation of feeding behavior and locomotor or psychomotor activity by CRH and its related peptides in fish, especially with reference to the goldfish model.

\section{CONTROL OF FOOD INTAKE BY CRH AND ITS RELATED PEPTIDES IN FISH}

The effects of ICV administration of neuropeptides on food intake in goldfish have been extensively studied. For example, ICV-injected ghrelin, neuropeptide Y, and orexin increase food consumption whereas $\mathrm{CRH}$, UI, proopiomelanocortin (POMC)-derived peptides such as $\alpha$-MSH, pituitary adenylate cyclase-activating polypeptide (PACAP), cholecystokinin (CCK), neuromedin $\mathrm{U}(\mathrm{NMU})$, and diazepam-binding inhibitor-derived peptides such as octadecaneuropeptide (ODN) decrease food intake (Matsuda, 2009). These neuropeptides are not independently involved in the control of feeding behavior, but mutually interact with each other. The anorexigenic actions of PACAP and NMU are abolished by treatment with $\alpha$-helical $\mathrm{CRH}_{(9-41)}$, and CCK- and ODN-evoked anorexigenic actions are also attenuated by treatment with the melanocortin 4 receptor 
(MC4R) antagonist HS024 (Maruyama et al., 2006, 2009; Kang et al., 2010; Matsuda et al., 2010a). These findings suggest that $\mathrm{CRH}$ and $\alpha-\mathrm{MSH}$ mediate the actions of PACAP and NMU, and $\mathrm{CCK}$ and ODN, respectively. In goldfish, $\alpha-\mathrm{MSH}$-containing nerve fibers or endings lie in close apposition to CRH-containing neurons in a specific region of the hypothalamus, the nucleus posterioris periventricularis $(\mathrm{NPPv})$. The anorexigenic action of the $\alpha-\mathrm{MSH}$ agonist melanotan II (MT II) is abolished by treatment with $\alpha$-helical $\mathrm{CRH}_{(9-41)}$ whereas the anorexigenic action of CRH is not affected by treatment with HS024 (Matsuda et al., 2008a). These observations indicate that, in goldfish, $\alpha-\mathrm{MSH}-$ induced anorexigenic action is mediated by the $\mathrm{CRH}$-signaling pathway, and that $\mathrm{CRH}$ plays a crucial role in the regulation of feeding behavior as an integrated anorexigenic neuropeptide in this species.

The distribution of CRH in the brain of teleost fish including the goldfish, has been well-reported: CRH-containing neuronal cell bodies are localized in various hypothalamic regions, including the preopticus periventricularis (NPP), the nucleus preopticus (NPO), the lateral part of the nucleus lateralis tuberis (NLTl) and the NPPv, and CRH-containing fibers or endings are distributed throughout the brain, and in the neurohypophysis (Olivereau et al., 1984, 1988; Yulis et al., 1986; Yulis and Lederis, 1987). For example, in goldfish, neuronal cell bodies exhibiting $\mathrm{CRH}$-like immunoreactivity are located mainly in the preoptic parvocellular areas comprising the NPP and NPO, the $\mathrm{NLTl}$, and paraventricular organ areas such as the NPPv, and their fibers are distributed in the diencephalon, mesencephalon, and neurohypophysis. $\mathrm{CRH}$-containing neurons that originate in the NPP and NPO parvocellular population seem to innervate the pituitary. As described above, studies of the effect of $\mathrm{CRH}$ on feeding behavior in goldfish have shown that it acts as a powerful hypothalamic anorexigenic peptide (de Pedro et al., 1993, 1997; Bernier et al., 1999, 2004; Bernier and Peter, 2001; Maruyama et al., 2006). Interestingly, we and others have found that ICV injection of gonadotropin-releasing hormone $2(\mathrm{GnRH} 2$, also known as chicken GnRH II) affects food consumption, and that GnRH2 decreases food intake (Hoskins et al., 2008; Matsuda et al., $2008 \mathrm{~b})$. Subsequently it has been indicated that the anorexigenic actions of CRH and $\alpha-\mathrm{MSH}$ are blocked by treatment with the GnRH type I receptor antagonist Antide, suggesting that GnRH2 mediates the actions of other anorexigenic neuropeptides examined so far, and that GnRH2 acts as a key neuropeptide exerting satiety control (Kang et al., 2011).

\section{PSYCHOPHYSIOLOGICAL EFFECT OF CRH IN FISH}

Recent studies have shown that several neuropeptides such as $\mathrm{CRH}, \mathrm{GnRH} 2, \mathrm{ODN}, \mathrm{PACAP}$, NPY, ghrelin, and orexin affect not only food intake but also locomotor activity in fish (Table 1): ICV injection of CRH enhances swimming distance, and stimulates locomotor activity (Maruyama et al., 2006; Carpenter et al., 2007; Backström et al., 2011a,b; Matsuda et al., 2013b). Psychophysiological compounds including diazepam, serotonin, a selective serotonin reuptake inhibitor Fluoxetin, a centraltype benzodiazepine receptor inverse agonist FG-7142, and an $\mathrm{N}$-methyl-d-aspartate receptor antagonist MK-801 also modify locomotor activity (Kang et al., 2010; Matsuda et al., 2011b, 2013b; Winder et al., 2012). Recent reports have indicated that the swimming pattern of a fish in a tank can be used to evaluate psychomotor activity (Faganello and Mattioli, 2007; Cachat et al., 2010; Grossman et al., 2010; Maximino et al., 2010a,b; Khor et al., 2011, 2013; Matsuda et al., 2011a; Piato et al., 2011). The scototaxis test (light/dark preference test) has been developed, and used for measuring psychomotor activity (Faganello and Mattioli, 2007; Blaser and Rosemberg, 2012). Intact animals usually prefer the dark area to the light area, and psychophysiological substances affect this preference: treatment with diazepam increases the time spent in the light area, and treatment with

Table 1 | Effects of neuropeptides and psychophysiological compounds on food intake, locomotor activity, and emotional action in fish.

\begin{tabular}{|c|c|c|c|c|c|}
\hline Substances & Species & Food intake & Locomotor activity & Emotional action & References \\
\hline \multirow[t]{2}{*}{$\mathrm{CRH}$} & Goldfish & Down & Up & Anxiogenic-like & Maruyama et al., 2006; Matsuda et al., 2013b \\
\hline & Rainbow trout & & Up & Anxiogenic-like & Carpenter et al., 2007; Backström et al., 2011a,b \\
\hline \multirow[t]{2}{*}{$\mathrm{GnRH} 2$} & Goldfish & Down & Up & & Hoskins et al., 2008; Matsuda et al., 2008b \\
\hline & Zebrafish & Down & & & Nishiguchi et al., 2012 \\
\hline ODN & Goldfish & Down & Up & Anxiogenic-like & Matsuda et al., 2007, 2011b \\
\hline PACAP & Goldfish & Down & Up & Anxiogenic-like & Matsuda et al., 2006a, 2013a \\
\hline \multirow[t]{2}{*}{ NPY } & Goldfish & Up & Down & Anxiolytic-like & Matsuda et al., 2011a, 2012b \\
\hline & Zebrafish & Up & & & Yokobori et al., 2012 \\
\hline Ghrelin & Goldfish & Up & Up or Down & & Matsuda et al., 2006b; Yahashi et al., 2012 \\
\hline \multirow[t]{2}{*}{ ORX } & Goldfish & Up & Up & & Nakamachi et al., 2006; Matsuda et al., 2012a \\
\hline & Zebrafish & Up & Up & & Yokogawa et al., 2007; Yokobori et al., 2011 \\
\hline Diazepam & Goldfish & & Down & Anxiolytic-like & Matsuda et al., 2011b \\
\hline \multirow[t]{2}{*}{ Fluoxetine } & Sheepshead minnow & & Down & & Winder et al., 2012 \\
\hline & Chinook salmon & & Down & & Clements and Schreck, 2007 \\
\hline FG-7142 & Goldfish & & Up & Anxiogenic-like & Matsuda et al., 2011b \\
\hline MK-801 & Goldfish & & Up & & Kang et al., 2011 \\
\hline
\end{tabular}

Abbreviations: $\mathrm{CRH}$, corticotropin-releasing hormone; GnRH2, gonadotropin-releasing hormone 2; ODN, octadecaneuropeptide; PACAP, pituitary adenylate cyclaseactivating polypeptide; NPY, neuropeptide Y; ORX, orexin; Fluoxetine, a selective serotonin reuptake inhibitor; FG-7142, a central-type benzodiazepine receptor inverse agonist; $M K-801$, an N-methyl-d-aspartate receptor antagonist. 


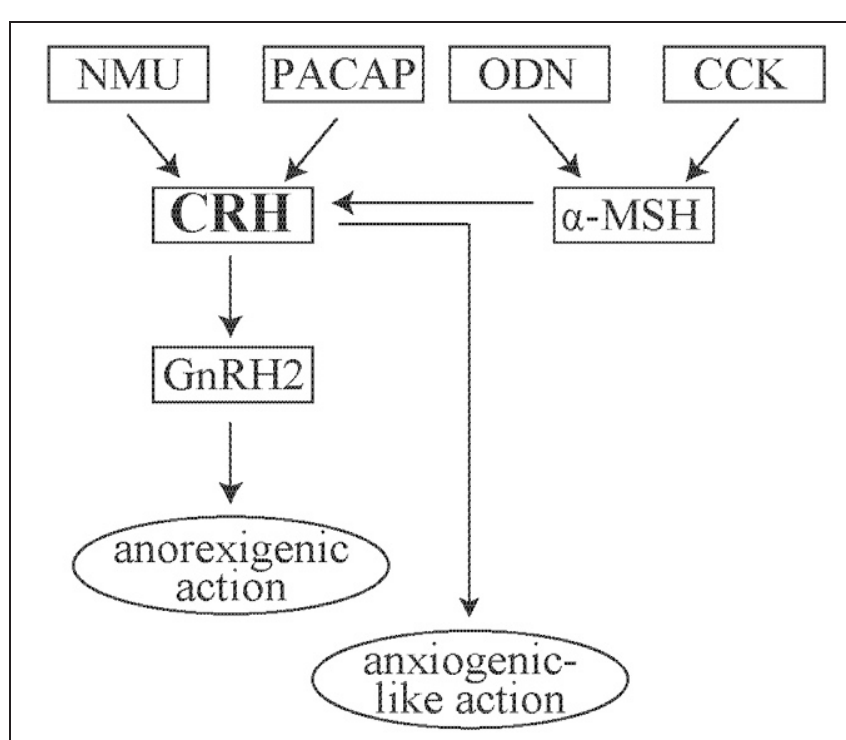

FIGURE 1 | Schematic drawings of the neuronal signaling pathways of anorexigenic and anxiogenic-like action in goldfish. ODN and CCK-induced anorexigenic actions are mediated by $\alpha-\mathrm{MSH}$-signaling pathway, and the anorexigenic actions of NMU, PACAP, and $\alpha-\mathrm{MSH}$ are mediated by $\mathrm{CRH}$ - and subsequent $\mathrm{GnRH} 2$-signaling pathways. $\mathrm{CRH}$ also evokes anxiogenic-like action. Abbreviations: NMU, neuromedin U; PACAP, pituitary adenylate cyclase-activating polypeptide; ODN,

octadecaneuropeptide; CCK, cholecystokinin; $\mathrm{CRH}$, corticotropin-releasing hormone; $\alpha-\mathrm{MSH}, \alpha$-melanocyte-stimulating hormone; $\mathrm{GnRH} 2$, gonadotropin-releasing hormone 2 .

FG-7142 increases the time spent in the dark area, suggesting that the former and latter treatments induce anxiolyticand anxiogenic-like actions, respectively (Matsuda et al., 2011b). Since intact goldfish and zebrafish prefer the lower to the upper area of a tank, another preference test has also been developed to evaluate the effect of CRH or other substances on psychomotor activity (Khor et al., 2013; Matsuda et al., 2013b). ICV

\section{REFERENCES}

Backström, T., Pettersson, A., Johansson, V., and Winberg, S. (2011a). CRF and urotensin I effects on aggression and anxietylike behavior in rainbow trout. J. Exp. Biol. 214, 907-914. doi: 10.1242/jeb.045070

Backström, T., Schjolden, J., Øverli, Ø., Thörnqvist, P. O., and Winberg, S. (2011b). Stress effects on AVT and CRF systems in two strains of rainbow trout (Oncorhynchus mykiss) divergent in stress responsiveness. Horm. Behav. 59, 180-186. doi: 10.1016/j.yhbeh.2010.11.008

Bernier, N. J. (2006). The corticotropin-releasing factor system as a mediator of the appetitesuppressing effects of stress in fish. Gen. Comp. Endocrinol. 146, 45-55. doi: 10.1016/j.ygcen.2005.11.016

Bernier, N. J., Bedard, N., and Peter, R. E. (2004). Effects of cortisol on food intake, growth, and forebrain neuropeptide $\mathrm{Y}$ and corticotropin-releasing factor gene expression in goldfish. Gen. Comp. Endocrinol. 135, 230-240. doi: 10.1016/j.ygcen.2003.09.016

Bernier, N. J., Lin, X., and Peter, R. E. (1999). Differential expression of corticotropin-releasing factor (CRF) and urotensin I precursor genes, and evidence of CRF gene expression regulated by cortisol in goldfish brain. Gen. Comp. Endocrinol. 116, 461-477. doi: 10.1006/gcen.1999.7386

Bernier, N. J., and Peter, R. E. (2001). The hypothalamic-pituitaryinterrenal axis and the control of food intake in teleost fish. Comp. Biochem. Physiol. B Biochem. Mol. Biol. 129, 639-644. doi: 10.1016/S1096-4959(01)00360-8

Blaser, R. E., and Rosemberg, D. B. (2012). Measures of anxiety in zebrafish (Danio rerio): dissociation of black/white preference

administration of CRH and FG-7142 both increase the time taken to move from the lower to the upper area, and the anxiogenic-like action of CRH is blocked by treatment with $\alpha$-helical $\mathrm{CRH}_{(9-41)}$ (Matsuda et al., 2013b). Recent studies of other fish have also indicated that $\mathrm{CRH}$ induces behavioral changes including anxiety and suppression of aggressive behavior (Lastein et al., 2008; Carpenter et al., 2009; Backström et al., 2011a,b; Ghisleni et al., 2012). These studies suggest that CRH exerts psychophysiological effects as an anxiogenic factor in addition to satiety control in fish. Figure 1 shows a schematic drawing of the anorexigenic signaling pathways mediated by $\mathrm{CRH}$ and other neuropeptides in the central nervous system of goldfish. As described above, CRH also evokes anxiogenic-like action in this species. Although it is unclear why regulation of food intake and the psychophysiological effects of CRH are closely linked, CRH appears to induce both anorexigenic- and anxiogenic-like actions in fish. Therefore, it is reasonable to suggest that the increased locomotor activity of fish in an experimental tank induced by CRH can be interpreted as escape behavior triggered by the anxiogenic-like action of $\mathrm{CRH}$ and subsequent stress response. Further study is warranted to clarify the function of $\mathrm{CRH}$ and its related peptides in the regulation of feeding and emotional activity in fish.

\section{CONCLUSION}

In fish, CRH exerts potential effects on food intake, as well as locomotor and psychomotor activities, providing an example of a neuropeptide that regulates both feeding behavior and psychophysiological activity such as anxiogenic- or anxiolytic-like action.

\section{ACKNOWLEDGMENTS}

This work was supported by a Grant-in-Aid from the Japan Society for the Promotion of Science (21370025 to Kouhei Matsuda), and by research grants from the University of Toyama (Kouhei Matsuda).

and novel tank test. PLoS ONE 7:e36931. doi: 10.1371/journal. pone.0036931

Boorse, G. C., and Denver, R. J. (2004). Expression and hypophysiotropic actions of corticotropin-releasing factor in Xenopus laevis. Gen. Comp. Endocrinol. 137, 272-282. doi: 10.1016/j.ygcen.2004.04.001

Boorse, G. C., and Denver, R. J. (2006). Widespread tissue distribution and diverse functions of corticotropin-releasing factor and related peptides. Gen. Comp. Endocrinol. 146, 9-18. doi: 10.1016/j.ygcen.2005.11.014

Cachat, J., Stewart, A., Grossman, L., Gaikwad, S., Kadri, F., Chung, K. M., et al. (2010). Measuring behavioral and endocrine responses to novelty stress in adult zebrafish. Nat. Protoc. 5, 1786-1799. doi: 10.1038/nprot.2010.140

Calle, M., Corstens, G. J., Wang, L., Kozicz, T., Denver, R. J., Barendregt,
H. P., et al. (2005). Evidence that urocortin I acts as a neurohormone to stimulate $\alpha \mathrm{MSH}$ release in the toad Xenopus laevis. Brain Res. 1040, 14-28. doi: 10.1016/j.brainres.2004.12.056

Carpenter, R. E., Korzan, W. J., Bockholt, C., Watt, M. J., Forster, G. L., Renner, K. J., et al. (2009). Corticotropin releasing factor influences aggression and monoamines: modulation of attacks and retreats. Neuroscience 158, 412-425. doi: 10.1016/j.neuroscience.2008.10.014 Carpenter, R. E., Watt, M. J., Forster, G. L., Øverli, Ø., Bockholt, C., Renner, K. J., et al. (2007). Corticotropin releasing factor induces anxiogenic locomotion in trout and alters serotonergic and dopaminergic activity. Horm. Behav. 52, 600-611. doi: 10. 1016/j.yhbeh.2007.07.012

Carr, J. A., Lustgarten, J., Ahmed, N., Bergfeld, N., Bulin, S. E., Shoukfeh, O., et al. (2010). The organization 
of CRF neuronal pathways in toads: evidence that retinal afferents do not contribute significantly to tectal CRF content. Brain Behav. Evol. 76, 71-86. doi: 10.1159/000319555

Chen, Y. W., Rada, P. V., Bützler, B. P., Leibowitz, S. F., and Hoebel, B. G. (2012). Corticotropinreleasing factor in the nucleus accumbens shell induces swim depression, anxiety, and anhedonia along with changes in local dopamine/acetylcholine balance. Neuroscience 206, 155-166. doi: 10.1016/j.neuroscience.2011.12.009

Clements, S., and Schreck, C. B. (2004). Central administration of corticotropin-releasing hormone alters downstream movement in an artificial stream in juvenile chinook salmon (Oncorhynchus tshawytscha). Gen. Comp. Endocrinol. 137, 1-8. doi: 10.1016/j.ygcen.2004.02.004

Clements, S., and Schreck, C. B. (2007). Chronic administration of fluoxetine alters locomotor behavior, but does not potentiate the locomotor stimulating effects of $\mathrm{CRH}$ in juvenile Chinook salmon (Oncorhynchus tshawytscha). Comp. Biochem. Physiol. A Mol. Integr. Physiol. 147, 43-49. doi: 10.1016/j.cbpa.2006.11.011

Cooper, M. A., and Huhman, K. L. (2007). Corticotropin-releasing factor receptors in the dorsal raphe nucleus modulate social behavior in Syrian hamsters. Psychopharmacology 194, 297-307. doi: 10.1007/s00213-007-0849-1

Denver, R. J. (2009). Structural and functional evolution of vertebrate neuroendocrine stress systems. Ann. N.Y. Acad. Sci. 1163, 1-16. doi: 10.1111/j.1749-6632. 2009.04433.x

de Pedro, N., Alonso-Gomez, A. L., Gancedo, B., Delgado, M. J., and Alonso-Bedate, M. (1993). Role of corticotropinreleasing factor (CRF) as a food intake regulator in goldfish. Physiol. Behav. 53, 517-520. doi: 10.1016/0031-9384(93)90146-7

de Pedro, N., Alonso-Gómez, A. L., Gancedo, B., Valenciano, A. I., Delgado, M. J., and AlonsoBedate, M. (1997). Effect of alpha-helical-CRF[9-41] on feeding in goldfish: involvement of cortisol and catecholamines. Behav. Neurosci. 111, 398-403. doi: 10.1037/0735-7044.111.2.398

Faganello, F. R., and Mattioli, R. (2007). Anxiolytic-like effect of chlorpheniramine in inhibitory avoidance in goldfish submitted to telencephalic ablation.
Prog. Neuropsychopharmacol. Biol. Psychiatry 31, 269-274. doi: 10.1016/j.pnpbp.2006.06.015

Ghisleni, G., Capiotti, K. M., Da Silva, R. S., Oses, J. P., Piato, Â. L., Soares, V., et al. (2012). The role of $\mathrm{CRH}$ in behavioral responses to acute restraint stress in zebrafish. Prog. Neuropsychopharmacol. Biol. Psychiatry 36, 176-182. doi: 10.1016/j.pnpbp.2011.08.016

Grossman, L., Utterback, E., Stewart, A., Gaikwad, S., Chung, K. M., Suciu, C., et al. (2010). Characterization of behavioral and endocrine effects of LSD on zebrafish. Behav. Brain Res. 214, 277-284. doi: 10.1016/j.bbr.2010.05.039

Hauger, R. L., Millan, M. A., Lorang, M., Harwood, J. P., and Aguilera, G. (1988). Corticotropin-releasing factor receptors and pituitary adrenal responses during immobilization stress. Endocrinology 123, 396-405.

Hauger, R. L., Risbrough, V., Brauns, O., and Dautzenberg, F. M. (2006). Corticotropin releasing factor (CRF) receptor signaling in the central nervous system: new molecular targets. CNS Neurol. Disord. Drug Targets 5, 453-479. doi: 10.2174/187152706777950684

Hillebrand, J. J., de Wied, D., and Adan, R. A. (2002). Neuropeptides, food intake and body weight regulation: a hypothalamic focus. Peptides 23, 2283-2306. doi: 10.1016/S01969781(02)00269-3

Hoskins, L. J., Xu, M., and Volkoff, H. (2008). Interactions between gonadotropin-releasing hormone $(\mathrm{GnRH})$ and orexin in the regulation of feeding and reproduction in goldfish (Carassius auratus). Horm. Behav. 54, 379-385. doi: 10.1016/j.yhbeh.2008.04.011

Ito, Y., Okada, R., Takahashi, N., and Kikuyama, S. (2006). Cloning and distribution of the bullfrog type 1 and type 2 corticotropinreleasing factor receptors. Gen. Comp. Endocrinol. 146, 291-295. doi: 10.1016/j.ygcen.2005.11.001

Kalra, S. P., Dube, M. G., Pu, S., $\mathrm{Xu}$, B., Horvath, T. L., and Kalra, P. S. (1999). Interacting appetite-regulating pathways in the hypothalamic regulation of body weight. Endocr. Rev. 20, 68-100. doi: 10.1210/er.20.1.68

Kang, K. S., Shimizu, K., Azuma, M., Ui, Y., Nakamura, K., Uchiyama, M., et al. (2011). Gonadotropin-releasing hormone II $(\mathrm{GnRH}$ II) mediates the anorexigenic actions of $\alpha$ melanocyte-stimulating hormone
$(\alpha-\mathrm{MSH})$ and corticotropinreleasing hormone (CRH) in goldfish. Peptides 32, 31-35. doi: 10.1016/j.peptides.2010.10.013

Kang, K. S., Yahashi, S., Azuma, M., and Matsuda, K. (2010). The anorexigenic effect of cholecystokinin octapeptide in a goldfish model is mediated by the vagal afferent and subsequently through the melanocortin- and corticotropinreleasing hormone-signaling pathways. Peptides 31, 2130-2134. doi: 10.1016/j.peptides.2010.07.019

Khan, M. S., Cline, M. A., Aramaki, T., Ueda, H., and Tachibana, T. (2013). Feeding response following central administration of chicken vasoactive intestinal peptide in chicks. Gen. Comp. Endocrinol. 184, 61-66. doi: 10.1016/j.ygcen.2013.01.002

Khor, B.-S., Jamil, M. F. A., Adenan, M. I., and Shu-Chien, A. C. (2011) Mitragynine attenuates withdrawal syndrome in morphine-withdrawn zebrafish. Plos ONE 6:e28340. doi: 10.1371/journal.pone.0028340

Khor, Y. M., Soga, T., and Parhar, I. S. (2013). Caffeine neuroprotects against dexamethasone-induced anxiety-like behaviour in the Zebrafish (Danio rerio). Gen. Comp. Endocrinol. 181, 310-315. doi: 10.1016/j.ygcen.2012.09.021

Kubota, N., Amemiya, S., Motoki, C. Otsuka, T., Nishijima, T., and Kita, I. (2012). Corticotropin-releasing factor antagonist reduces activation of noradrenalin and serotonin neurons in the locus coeruleus and dorsal raphe in the arousal response accompanied by yawning behavior in rats. Neurosci. Res. 72 , 316-323. doi: 10.1016/j.neures. 2012.01.001

Lastein, S., Höglund, E., Øverli, Ø., and Døving, K. B. (2008). Effects of antalarmin, a CRF receptor 1 antagonist, on fright reaction and endocrine stress response in crucian carp (Carassius carassius). J. Comp. Physiol. A Neuroethol. Sens. Neural Behav. Physiol. 194, 1007-1012. doi: 10.1007/s00359-008-0372-9

Lovejoy, D., and Balment, R. (1999). Evolution and physiology of the corticotrophin-releasing factor (CRF) family of neuropeptides in vertebrates. Gen. Comp. Endocrinol. 115, 1-22. doi: 10.1006/gcen.1999.7298

Lowry, C. A., and Moore, F. L. (2006). Regulation of behavioral responses by corticotorpin-releasing factor. Gen. Comp. Endocrinol. 146, 19-27. doi: 10.1016/j.ygcen.2005.12.006

Maaswinkel, H., Zhu, L., and Weng, W. (2012). The immediate and the delayed effects of buspirone on zebrafish (Danio rerio) in an open field test: a 3-D approach. Behav. Brain Res. 234, 365-374. doi: 10.1016/j.bbr.2012.07.014

Maruyama, K., Miura, T., Uchiyama, M., Shioda, S., and Matsuda, K. (2006). Relationship between anorexigenic action of pituitary adenylate cyclase-activating polypeptide (PACAP) and that of corticotropin-releasing hormone $(\mathrm{CRH})$ in the goldfish, Carassius auratus. Peptides 27, 1820-1826. doi: 10.1016/j.peptides.2006.01.013

Maruyama, K., Wada, K., Ishiguro, K., Shimakura, S. I., Wakasugi, T., Uchiyama, M., et al. (2009). Neuromedin U-induced anorexigenic action is mediated by the corticotropin-releasing hormone receptor-signaling pathway in goldfish. Peptides 30, 2483-2486. doi: 10.1016/j.peptides.2009.08.013

Matsuda, K. (2009). Recent advances in the regulation of feeding behavior by neuropeptides in fish. Ann. N.Y. Acad. Sci. 1163, 241-250. doi: 10.1111/j.17496632.2008.03619. $\mathrm{x}$

Matsuda, K., Azuma, M., and Kang, K. S. (2012a). Orexin system in teleost fish. Vitam. Horm. 89, 341-361. doi: 10.1016/B978-0-12-3946232.00018-4

Matsuda, K., Sakashita, A., Yokobori, E., and Azuma, M. (2012b). Neuroendocrine control of feeding behavior and psychomotor activity by neuropeptide $\mathrm{Y}$ in fish. Neuropeptides 46, 275-283. doi: 10.1016/j.npep.2012.09.006

Matsuda, K., Azuma, M., Maruyama, K., and Shioda, S. (2013a). Neuroendocrine control of feeding behavior and psychomotor activity by pituitary adenylate cyclaseactivating polypeptide (PACAP) in vertebrates. Obes. Res. Clin. Pract. 7 , e1-e7.

Matsuda, K., Hagiwara, Y., Shibata, H., and Wada, K., (2013b). Ovine corticotropin-releasing hormone (CRH) exerts an anxiogenic-like action in the goldfish, Carassius auratus. Gen. Comp. Endocrinol. doi: 10.1016/j.ygcen.2013.01.001. [Epub ahead of print].

Matsuda, K., Kang, K. S., Sakashita, A., Yahashi, S., and Vaudry, H. (2011a). Behavioral effect of neuropeptides related to feeding regulation in fish. Ann. N.Y. Acad. Sci. 1220, 117-126. doi: 10.1111/j.1749-6632.2010.05884.x

Matsuda, K., Wada, K., Azuma, M., Leprince, J., Tonon, M. C., Sakashita, A., et al. (2011b). The octadecaneuropeptide exerts an anxiogenic-like action in goldfish. 
Neuroscience 181, 100-108. doi: 10.1016/j.neuroscience.2011.02.058 Matsuda, K., Kojima, K., Shimakura, S. I., Wada, K., Maruyama, K., Uchiyama, M., et al. (2008a). Corticotropin-releasing hormone mediates $\alpha$-melanocyte-stimulating hormone-induced anorexigenic action in goldfish. Peptides 29, 1930-1936. doi: 10.1016/j.peptides.2008.06.028

Matsuda, K., Nakamura, K., Shimakura, S. I., Miura, T., Kageyama, H., Uchiyama, M., et al. (2008b). Inhibitory effect of chicken gonadotropin-releasing hormone II on food intake in the goldfish, Carassius auratus. Horm. Behav. 54, 83-89. doi: 10.1016/j.yhbeh.2008.01.011

Matsuda, K., Kojima, K., Wada, K., Maruyama, K., Leprince, J., Tonon, M. C., et al. (2010a). The anorexigenic action of the octadecaneuropeptide ODN in goldfish is mediated through the MC4R- and subsequently the $\mathrm{CRH}$ receptor-signaling pathways. J. Mol. Neurosci. 42, 74-79. doi: 10.1007/s12031-010-9346-9

Matsuda, K., Morimoto, N., Hashimoto, K., Okada, R., Mochida, H., Uchiyama, M., et al. (2010b). Changes in the distribution of corticotropin-releasing factor (CRF)-like immunoreactivity in the larval bullfrog brain and the involvement of CRF in the cessation of food intake during metamorphosis. Gen. Comp. Endocrinol. 168, 280-286. doi: 10.1016/j.ygcen.2010.01.004

Matsuda, K., Maruyama, K., Nakamachi, T., Miura, T., and Shioda, S. (2006a). Effects of pituitary adenylate cyclase-activating polypeptide (PACAP) and vasoactive intestinal peptide (VIP) on food intake and locomotor activity in the goldfish, Carassius auratus. Ann. N.Y. Acad. Sci. 1070, 417-421. doi: 10.1196/annals. 1317.054

Matsuda, K., Miura, T., Kaiya, H., Maruyama, K., Uchiyama, M., Kangawa, K., et al. (2006b). Stimulatory effect of $n$-octanoylated ghrelin on locomotor activity in the goldfish, Carassius auratus. Peptides 27, 1335-1340. doi: 10.1016/j.peptides.2005.10.011

Matsuda, K., Wada, K., Miura, T., Maruyama, K., Shimakura, S. I., Uchiyama, M., et al. (2007). Effect of the diazepam-binding inhibitor-derived peptide, octadecaneuropeptide, on food intake in goldfish. Neuroscience 150, 425-432. doi: 10.1016/j.neuroscience.2007.09.012
Maximino, C., Marcues de Brito, T., Colmanetti, R., Pontes, A. A., de Castro, H. M., de Lacerda, R. I., et al. (2010a). Parametric analyses of anxiety in zebrafish scototaxis. Behav. Brain Res. 210, 1-7. doi: 10.1016/j.bbr.2010.01.031

Maximino, C., Marcues de Brito, T., Dias, C. A., Gouveia, A. Jr., and Morato, S. (2010b). Scotaxis as anxiety-like behavior in fish. Nat. Protoc. 5, 209-216. doi: 10.1038/nprot.2009.225

Morimoto, N., Hashimoto, K., Okada, R., Mochida, H., Uchiyama, M., Kikuyama, S., et al. (2011). Inhibitory effect of corticotropinreleasing factor on food intake in the bullfrog, Aquarana catesbeiana. Peptides 32, 1872-1875. doi: 10.1016/j.peptides.2011.08.007

Nakamachi, T., Matsuda, K., Maruyama, K., Miura, T., Uchiyama, M. Funahashi, H., et al. (2006). Regulation by orexin of feeding behaviour and locomotor activity in the goldfish. J. Neuroendocrinol. 18, 290-297. doi: 10.1111/j.13652826.2006.01415.x

Nishiguchi, R., Azuma, M., Yokobori, E., Uchiyama, M., and Matsuda, K. (2012). Gonadotropin-releasing hormone 2 suppresses food intake in the zebrafish, Danio rerio. Front. Endocrinol. (Lausanne) 3:122. doi: 10.3389/fendo.2012.00122

Ohgushi, A., Bungo, T., Shimojo, M., Masuda, Y., Denbow, D. M., and Furuse, M. (2001). Relationships between feeding and locomotion behaviors after central administration of CRF in chicks. Physiol. Behav. 72, 287-289. doi: 10.1016/S0031-9384(00)00377-2

Okada, R., Miller, M. F., Yamamoto, K., De Groef, B., Denver, R. J., and Kikuyama, S. (2007). Involvement of the corticotropin-releasing factor (CRF) type 2 receptor in CRFinduced thyrotropin release by the amphibian pituitary gland. Gen. Comp. Endocrinol. 150, 437-444. doi: 10.1016/j.ygcen.2006.11.002

Olivereau, M., Moons, L., Olivereau, J., and Vandesande, F. (1988). Coexistence of corticotropin-releasing factorlike immunoreactivity and vasotocin in perikarya of the preoptic nucleus in the eel. Gen. Comp. Endocrinol. 70, 41-48. doi: 10.1016/0016-6480(88)90092-5

Olivereau, M., Ollevier, F., Vandesande, F., and Verdonck, W. (1984). Immunocytochemical identification of CRF-like and SRIF-like peptides in the brain and the pituitary of cyprinid fish. Cell Tissue Res. 237, 379-382. doi: 10.1007/BF00217162
Papadimitriou, A., and Priftis, K. N. (2009). Regulation of the hypothalamic-pituitary-adrenal axis. Neuroimmunomodulation 16, 265-271. doi: 10.1159/000216184

Piato, A. L., Capiotti, K. M., Tamborski, A. R., Oses, J. P., Barcellos, L. J. G., Bogo, M. R., et al. (2011). Unpredictable chronic stress model in zebrafish (Danio rerio): behavioral and physiological responses. Prog. Neuropsychopharmacol. Biol. Psychiatry 35, 561-567. doi: 10.1016/j.pnpbp.2010.12.018

Saito, E. S., Kaiya, H., Tachibana, T., Tomonaga, S., Denbow, D M., Kangawa, K., et al. (2005). Inhibitory effect of ghrelin on food intake is mediated by the corticotropin-releasing factor system in neonatal chicks. Regul. Pept. 125, 201-208. doi: 10.1016/j.regpep.2004.09.003

Tachibana, T., Saito, E. S., Takahashi, H., Saito, S., Tomonaga, S., Boswell, T., et al. (2004). Anorexigenic effects of pituitary adenylate cyclase-activating polypeptide and vasoactive intestinal peptide in the chick brain are mediated by corticotrophin-releasing factor. Regul. Pept. 120, 99-105. doi: 10.1016/j.regpep.2004.02.016

Tonon, M. C., Cuet, P., Lamacz, M., Jégou, S., Côté, J., Gouteaux, L., et al. (1986). Comparative effects of corticotropin-releasing factor, arginine vasopressin, and related neuropeptides on the secretion of ACTH and alphaMSH by frog anterior pituitary cells and neurointermediate lobes in vitro. Gen. Comp. Endocrinol. 61 , 438-445.

Vale, W., Spiess, J., Rivier, C., and Rivier, J. (1981). Characterization of a 41 residue ovine hypothalamic peptide that stimulates secretion of corticotropin and $\beta$-endorphin. Science 213, 1394-1397. doi: 10.1126/science.6267699

Volkoff, H., Canosa, L. F., Unniappan, S., Cerdá-Reverter, J. M., Bernier, N. J., Kelly, S. P., et al. (2005). Neuropeptides and the control of food intake in fish. Gen. Comp. Endocrinol. 142, 3-19. doi: 10.1016/j.ygcen.2004.11.001

Winder, V. L., Pennington, P. L., Hurd, M. W., and Wirth, E. F. (2012). Fluoxetine effects on sheepshead minnow (Cyprinodon variegatus) locomotor activity. J. Environ. Sci. Health B 47, 51-58. doi: 10.1080/03601234.2012.607767

Yahashi, S., Kang, K. S., Kaiya, H., and Matsuda, K. (2012). GHRP-6 mimics ghrelin-induced stimulation of food intake and suppression of locomotor activity in goldfish. Peptides 34, 324-328. doi: 10.1016/j.peptides. 2012.01.025

Yokobori, E., Azuma, M., Nishiguchi, R., Kang, K. S., Uchiyama, M., and Matsuda, K. (2012). Neuropeptide Y stimulates food intake in the zebrafish, Danio rerio. J. Neuroendocrinol. 24, 766-773. doi: $\quad 10.1111 / \mathrm{j} .1365-2826.2012$. 02281.x

Yokobori, E., Kojima, K., Azuma, M., Kang, K. S., Maejima, S., Uchiyama M., et al. (2011). Stimulatory effect of intracerebroventricular administration of orexin $\mathrm{A}$ on food intake in the zebrafish, Danio rerio. Peptides 32, 1357-1362. doi: 10.1016/j.peptides.2011.05.010

Yokogawa, T., Marin, W., Faraco, J., Pézeron, G., Appelbaum, L., Zhang, J., et al. (2007). Characterization of sleep in zebrafish and insomnia in hypocretin receptor mutants. PLoS Biol. 5:e277. doi: 10.1371/journal.pbio.0050277

Yulis, C. R., and Lederis, K. (1987). Co-localization of the immunoreactivities of corticotropin-releasing factor and arginine vasotocin in the brain and pituitary system of the teleost Catostomus commersoni. Cell Tissue Res. 247, 267-273. doi: 10.1007/BF00218308

Yulis, C. R., Lederis, K., Wong, K. L., and Fisher, A. W. (1986). Localization of urotensin I- and corticotropin-releasing factor-like immunoreactivity in the central nervous system of Catostomus commersoni. Peptides 7, 79-86.

Conflict of Interest Statement: The author declares that the research was conducted in the absence of any commercial or financial relationships that could be construed as a potential conflict of interest.

Received: 29 March 2013; accepted: 14 May 2013; published online: 30 May 2013.

Citation: Matsuda K (2013) Regulation of feeding behavior and psychomotor activity by corticotropin-releasing hormone (CRH) in fish. Front. Neurosci. 7:91. doi: 10.3389/fnins.2013.00091

This article was submitted to Frontiers in Neuroendocrine Science, a specialty of Frontiers in Neuroscience.

Copyright (c) 2013 Matsuda. This is an open-access article distributed under the terms of the Creative Commons Attribution License, which permits use, distribution and reproduction in other forums, provided the original authors and source are credited and subject to any copyright notices concerning any thirdparty graphics etc. 